\title{
Islet Transplantation and Insulin Administration Relieve Long-Term Complications and Rescue the Residual Endogenous Pancreatic $\beta$ Cells
}

\author{
Marina Figliuzzi, ${ }^{*}$ Roberto Bianchi, ${ }^{\dagger}$ Cristina Cavagnini, ${ }^{*}$ Raffaella Lombardi, ${ }^{\dagger}$ Carla Porretta-Serapiglia, ${ }^{\dagger}$ Giuseppe Lauria,

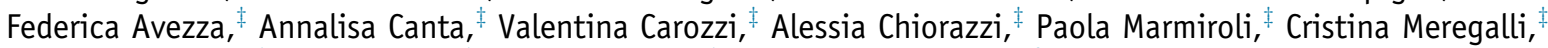 \\ Norberto Oggioni, ${ }^{\ddagger}$ Barbara Sala, ${ }^{\ddagger}$ Guido Cavaletti, ${ }^{\ddagger}$ and Andrea Remuzzi ${ }^{\star}$
}

\begin{abstract}
From the Department of Biomedical Engineering, * Mario Negri Institute for Pharmacological Research, IRCCS-Institute for Research, Hospitalization, and Scientific Care, Bergamo; the Neuromuscular Diseases Unit, ${ }^{\dagger}$ Foundation IRCCS Carlo Besta National Neurological Institute, Milan; the Experimental Neurology Unit, ${ }^{\ddagger}$ Department of Surgery and Translational Medicine, University of Milan-Bicocca, Monza; and the Department of Industrial Engineering, University of Bergamo, Dalmine, Italy
\end{abstract}

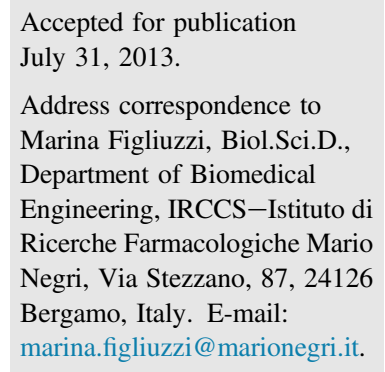

\begin{abstract}
Islet transplantation is a poorly investigated long-term strategy for insulin replacement and for treatment of complications in patients with diabetes. We investigated whether islet transplantation and insulin treatment can relieve diabetic neuropathy and rescue the residual endogenous pancreatic $\beta$ cells. We used a multimodal approach, with five groups of Sprague-Dawley rats studied for 8 months: control rats, diabetic rats, insulin-treated diabetic rats with moderate or mild hyperglycemia, and diabetic rats transplanted with microencapsulated islets. Islet transplantation normalized glycemia and increased body and muscle weight; it was also effective in reducing proteinuria and altered liver function. Transplantation significantly improved tail nerve conduction velocity, $\mathrm{Na}^{+}-\mathrm{K}^{+}$-ATPase activity, and morphological alterations in the sciatic nerve as evidenced by decrease in $g$-ratio; it also restored thermal and ameliorated mechanical nociceptive thresholds. Morphometric analysis of pancreas indicated a significant $\beta$-cell volume increase in transplanted rats, compared with mildly and moderately hyperglycemic rats. Thus, allogeneic islet transplantation had a positive systemic effect in diabetic rats and induced regression of the established neuropathy and restitution of the typical characteristics of the islets. These findings strongly reinforce the need for improving glycemic control, not only to reverse established diabetic complications but also to improve $\beta$-cell status in diabetic pancreas. (Am J Pathol 2013, 183: 1527-1538; http://dx.doi.org/10.1016/j.ajpath.2013.07.032)
\end{abstract}

Type 1 diabetes is characterized by deficiency of insulin secretion due to the loss of $\beta$-cell mass by autoimmunity. Both $\beta$-cell mass and function decline with increasing duration of diabetes. ${ }^{1}$ The consequent chronic hyperglycemia is believed to be responsible for the development of diabetic complications such as neuropathy, retinopathy, nephropathy, and cardiovascular diseases. ${ }^{2}$ Of the diabetic population, $40 \%$ to $50 \%$ develop peripheral and autonomic neuropathies, ${ }^{3}$ which involve a spectrum of functional and structural changes in peripheral nerves, including sensory loss and pain. The signs of nerve degeneration consist of an early decrease of nerve conduction velocity (NCV) and of nerve action potential amplitude, reduction in $\mathrm{Na}^{+}-\mathrm{K}^{+}$ATPase activity, and changes in nociceptive thermal and mechanical thresholds. The maintenance of normoglycemia is the only therapy approved for peripheral neuropathy by regulatory bodies in Europe and the United States. The Diabetes Control and Complications Trial demonstrated that severity of neuropathy is related to the duration of disease and that improved glucose control reduces diabetic complications. $^{2}$ Currently, the only methods of providing physiologically regulated control of blood glucose in type 1 diabetic patients are pancreas and islet transplantation.

Our research group has previously reported that transplantation of microencapsulated syngeneic islets after 2 months of streptozotocin (STZ)-induced diabetes in rats produced normoglycemia, amelioration of impaired nociceptive thresholds, and normalization of NCV and of 
$\mathrm{Na}^{+}-\mathrm{K}^{+}$-ATPase activity in the sciatic nerve. ${ }^{4}$ In kidneys of diabetic rats, we observed mild tubular dilatation and tubular cast completely absent in the rats with transplanted islets, suggesting regression of these early signs of nephropathy. ${ }^{4}$

Few studies have addressed the effect of pancreatic islet transplantation on diabetes of long duration and on longterm complications. We therefore investigated the effect of islet transplantation in animals with a long duration of the disease, when, in addition to functional changes, structural changes are also expected to challenge the effectiveness of normoglycemic strategies.

We used two strategies to control glycemia, microencapsulated allogeneic islet transplantation and daily insulin injections, to obtain different levels of glycemia. To this end, we used two groups of diabetic rats: untreated diabetic rats and diabetic rats maintained in moderate hyperglycemia (300 to $400 \mathrm{mg} / \mathrm{dL}$ ). After 4 months, diabetic rats with insulin-regulated glycemia were divided into three groups; the first group was maintained under the same conditions, the second underwent transplantation with microencapsulated allogeneic rat islets, and the last group was treated with insulin to normalize glycemia. Animals were monitored for an additional 4 months. Thus, the overall duration of the study was 8 months from diabetes induction.

Although it has been reported that normoglycemia has protective effects in the maintenance of transplanted islets, ${ }^{4,5}$ few studies have addressed the question of whether islet transplantation may exert such an effect also on endogenous pancreatic islets. We therefore investigated, in STZ-diabetic rats, whether islet transplantation and/or glycemic control by insulin administration could relieve neuropathic complications and neuropathic pain and could rescue residual endogenous pancreatic $\beta$ cells.

\section{Materials and Methods}

\section{Experimental Design}

Male Lewis and Sprague-Dawley rats (Harlan Laboratories, Bresso, Italy; Indianapolis, IN), 12 weeks of age, were used as donors and recipients, respectively. Animal care and treatment were conducted in accordance with institutional guidelines and in compliance with national (Legislative decree 116, Official Gazette, Supplement 40, February 18, 1992, and Circular 8, Official Gazette, July 14, 1994) and international (European Economic Community Council Directive 86/609, OJL358-1, December 1987, and the U.S. National Research Council Guide for the Care and Use of Laboratory Animals, 1996) laws and policies. Animal studies were submitted to and approved by the Institutional Animal Care and Use Committee of the Mario Negri Institute for Pharmacological Research. Animals were kept on a 12-hour light/dark cycle with free access to water and food.
Rats were randomly assigned to three experimental groups: healthy rats (control), untreated diabetic rats (hyperglycemia), and diabetic rats treated subcutaneously with 1 to $15 \mathrm{IU}$ of human recombinant insulin (Lantus; Sanofi, Milan, Italy; Paris, France) to achieve blood glucose between 300 and $400 \mathrm{mg} / \mathrm{dL}$ (moderate hyperglycemia). Diabetes was induced by a single injection of $60 \mathrm{mg} / \mathrm{kg}$ i.p. STZ (Sigma-Aldrich, St. Louis, MO). Hyperglycemia was confirmed 48 hours after STZ injection by measurements of tail-vein blood glucose levels using a glucometer (Ascensia Elite; Bayer, Basel, Switzerland). At 4 months after diabetes induction, the moderate hyperglycemia group was further randomly divided into three groups: one that maintained the same level of glycemic control, another with insulin treatment to obtain normoglycemic status (mild hyperglycemia group), and a third that received islet transplantation. The groups of animals were monitored until 8 months from the beginning of the study. Body weight and blood glucose concentration, determined by tail bleeding, were measured daily.

Proteinuria was measured in 24-hour urine samples collected in metabolic cages at baseline and every month by the Coomassie Blue method using a Cobas Mira autoanalyzer (Roche, Basel, Switzerland).

\section{Isolation of Pancreatic Islets}

Islets were isolated from the pancreas of Lewis rats (250 to $300 \mathrm{~g}$ body weight) using an automated procedure as described previously. ${ }^{4}$ In brief, the pancreas of anesthetized rats was distended with collagenase $\mathrm{P}$ solution (Roche Diagnostics, Mannheim, Germany), removed, and loaded into a digestion chamber at $37^{\circ} \mathrm{C}$. When optimum digestion time was reached, the chamber was flushed with $4^{\circ} \mathrm{C}$ Hanks' balanced salt solution (HBSS; Life Technologies, Paisley, UK; Monza, Italy; Carlsbad, CA) and digested tissue was purified by centrifugation on a Histopaque density gradient $\left(1.077 \mathrm{~g} / \mathrm{mL}\right.$; Sigma-Aldrich). Islets were cultured at $37^{\circ} \mathrm{C}$ in a humidified, $5 \% \mathrm{CO}_{2}$-enriched atmosphere in RPMI 1640 medium (Life Technologies), supplemented with $10 \%$ fetal bovine serum (EuroClone, Pero, Italy).

\section{Encapsulation and Transplantation of Pancreatic Islets}

Islet encapsulation was performed as described previously. ${ }^{6}$ In brief, islets were suspended in $1.7 \%$ sodium alginate solution (Manugel DMB; Kelco Alginates, Tadworth, UK) at a concentration of 1 islet per microliter. The islet-alginate mixture was then extruded through an air-jet droplet generator into a $100 \mathrm{mmol} / \mathrm{L} \mathrm{CaCl}_{2}$ solution. Microcapsules containing 15,000 islets per kilogram body weight were implanted into the rat peritoneal cavity through a $1-$ to $2-\mathrm{cm}$ midline incision under isoflurane anesthesia.

\section{OGTT}

An oral glucose tolerance test (OGTT) was performed at 4 and 8 months from the beginning of the study by oral 
administration of $1 \mathrm{~g} / \mathrm{kg}$ of glucose after an overnight fast. Blood samples were taken from the tail vein immediately before and 15, 30, 60, 120, and 180 minutes after glucose administration. Blood glucose concentrations were measured using Ascensia Elite strips (Bayer). Total area under the curve (AUC) was then calculated.

\section{Behavioral Evaluation}

Thermal nociceptive threshold to radiant heat was quantified by using the paw-withdrawal test with a hot plate (Ugo Basile, Comerio, Italy). ${ }^{7}$ Withdrawal latency was defined as time between placement on the hot plate and time of withdrawal and licking of hind paw. The mechanical nociceptive threshold was quantified using the Randall-Selitto pawwithdrawal test ${ }^{7,8}$ with an Analgesy-meter (Ugo Basile, Comerio, Italy), which generates a linearly increasing mechanical force. The results indicate the maximum pressure tolerated by the animals. The two tests were performed every 4 weeks. For both determinations, animals were tested twice, with a 30-minute interval, and the values were averaged. For mechanical sensitivity, the test was performed first on the right leg and then on the left leg.

\section{NCV in the Tail}

NCV was measured by using a Myto EBNeuro electromyograph (EBNeuro, Florence, Italy) as described previously. ${ }^{9}$ In brief, the antidromic NCV in the tail was assessed by placing recording ring electrodes distally on the tail while stimulating ring electrodes were placed 5 and $10 \mathrm{~cm}$ proximally from the recording point. The latencies of the potentials recorded at the two sites after nerve stimulation were determined (peak-to-peak stimulus duration $100 \mathrm{~ms}$, filter $1 \mathrm{~Hz}$ to $5 \mathrm{MHz}$ ) and NCV was calculated. Determinations were performed under standard conditions in a temperature-controlled room. Core temperature was maintained at $37^{\circ} \mathrm{C}$ by using heating pads and lamps.

\section{Plasma and Tissue Collection}

At 4 and 8 months after the beginning of the study, animals were placed under ketamine-xylazine anesthesia and blood was collected from the abdominal aorta. At sacrifice, sciatic nerves and pancreas were dissected out. Blood specimens and tissues were immediately processed as described below. Serum was obtained by centrifugation of clotted blood at $2500 \times g$ for 15 minutes at $4^{\circ} \mathrm{C}$ and used for determination of blood urea nitrogen, creatinine, aspartate transaminase, and alanine transaminase with an automated Mira Plus system (Horiba ABX Diagnostic, Montpellier, France). ${ }^{10}$

\section{Plasma Thiobarbituric Acid-Reactive Substances}

EDTA and glutathione (1.34 and $0.65 \mathrm{mmol} / \mathrm{L}$ final concentrations, respectively) were immediately added to the collected plasma. Levels of thiobarbituric acid-reactive substances (TBARS) were determined, as an index of reactive oxygen species production, according to a protocol described previously. ${ }^{11}$

\section{$\mathrm{Na}^{+}-\mathrm{K}^{+}$-ATPase Activity}

$\mathrm{Na}^{+}-\mathrm{K}^{+}$-ATPase enzymatic activity in the sciatic nerve was assessed using a spectrophotometric method as described previously $^{12}$ with a coupled-enzyme assay ${ }^{13}$ on an Ultrospec 2100 pro spectrophotometer (GE Healthcare, Little Chalfont, UK). Protein content was determined with a DC
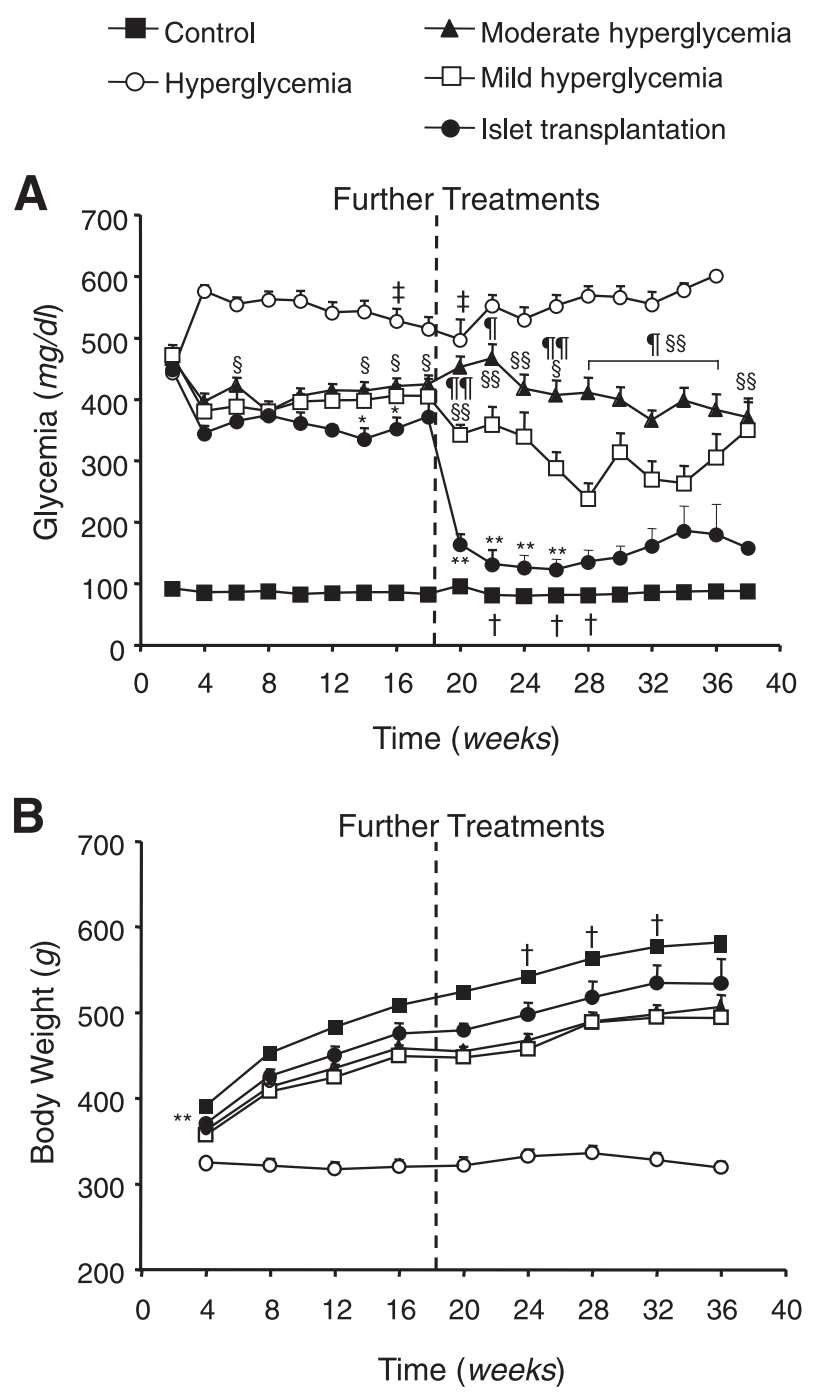

Figure 1 Blood glucose (A) and body weight (B) in male SpragueDawley rats. Data are expressed as means \pm SEM. $P<0.001$ for control versus all other groups at all time points. $P<0.001$ for hyperglycemia versus all other groups at all time point. ${ }^{*} P<0.05,{ }^{* *} P<0.001$ for islet transplantation versus mild hyperglycemia. ${ }^{\dagger} P<0.05$ for control versus islet transplantation. ${ }^{\ddagger} P<0.05$ for hyperglycemia versus mild hyperglycemia. $\S p<0.05, \S \S p<0.001$ for moderate hyperglycemia versus islet transplantation. ${ }^{\top} P<0.05,{ }^{\top} P<0.001$ for moderate hyperglycemia versus mild hyperglycemia. 
protein microplate assay protocol (Bio-Rad Laboratories, Milan, Italy; Hercules, CA).

\section{Pathological Assessment of Sciatic Nerve Myelinated Fibers}

The left sciatic nerves were removed, fixed by immersion in $3 \%$ glutaraldehyde, postfixed in $\mathrm{OsO}_{4}$, and embedded in epoxy resin for light microscope observation, as described previously. ${ }^{14}$ Toluidine Blue-stained semithin sections $(1 \mu \mathrm{m})$ were prepared from at least two tissue blocks for each animal and were examined with a Nikon Coolscope light microscope (Nikon Instruments, Calenzano, Italy; Tokyo, Japan). Semiautomated counting of myelinated fibers was performed with a light microscope (Nikon Eclipse E200) at $\times 60$ magnification; the morphometric analysis was performed using Leica QWin Quantitative Microscopy software (Leica Microsystems, Wetzlar, Germany). In randomly selected sections, all myelinated fibers evaluable in the analyzed space were counted on at least 500 myelinated fibers/nerves according to previously reported methods. ${ }^{15}$ At the same time, the $g$-ratio (the ratio of axonal diameter to myelin diameter) was calculated. Because on the cross-sections the shape of the axons was not always round, we calculated mean diameter from measured area, assuming that the ideal shape of the axon is a circle.

\section{Pancreas Processing}

Once removed, the pancreas was dissected from surrounding tissues and fixed by immersion in Bouin's solution (Diapath, Martinengo, Italy) for 4 hours at $4^{\circ} \mathrm{C}$. Samples were dehydrated in ascending concentrations of alcohol and embedded in paraffin. For each sample, 3- $\mu \mathrm{m}$ sections were obtained and processed for immunofluorescence analysis for glucagon or for immunohistochemical detection of insulin using the alkaline phosphate-Fast Red technique. For glucagon staining, 3- $\mu \mathrm{m}$ sections of tissue were saturated in $3 \%$ bovine serum albumin (Sigma-Aldrich) for 30 minutes at room temperature and then were incubated with the primary guinea pig polyclonal antibody to glucagon (1:1000; Acris Antibodies, Herford, Germany). Samples were then treated with 1:50 secondary fluorescein isothiocyanate goat anti-guinea pig antibody (Jackson ImmunoResearch Laboratories, West Grove, PA). Counterstaining with $1 \mu \mathrm{g} / \mathrm{mL}$ DAPI (Sigma-Aldrich) for 20 minutes at $37^{\circ} \mathrm{C}$ was performed for cell nuclear staining. The slides were finally mounted with a fluorescent mounting medium (Dako, Glostrup, Denmark; Carpinteria, CA) and examined under a Zeiss light microscope Axioimager.Z2 (Carl Zeiss Microscopy, Jena, Germany).

For insulin staining, slides were soaked in PBS-1\% bovine serum albumin for 30 minutes at room temperature, stained using mouse anti-insulin (1:3000; Sigma-Aldrich) for 2 hours at room temperature, and then incubated with horse biotinylated anti-mouse antibody (1:200; Vector Laboratories, Burlingame, CA) for 30 minutes. Last, slides were incubated with alkaline phosphatase-conjugated streptavidin (Roche, Mannheim, Germany) and counterstained with Harris-type hematoxylin (Bio-Optica, Milan, Italy).

\section{$\beta$-Cell Morphometric Analysis}

Tissue sections were examined under a Zeiss light microscope. For each sampling section, the area was scanned with a $20 \times$ objective using Zeiss AxioVision MosaiX software. Measurements were performed on digital images using ImageJ image analysis software version $1.47 \mathrm{~h}(\mathrm{NIH}$, Bethesda, MD). The volume density of insulin-positive cells was determined by point counting using an orthogonal grid with $17 \times 13$ lines digitally overlaid on the image of the stained section. For each islet, grid intersection points coinciding with positive-staining and negative-staining areas were counted.

Volume density was calculated as the percent ratio between grid points in the positive areas and the total points in the pancreatic islet. The mean area of insulin-positive cells was calculated by multiplying the number of grid points coinciding with positive staining by the unit area of the grid. Mean volume of islets $\left(V_{\mathrm{i}}, \mu \mathrm{m}^{3}\right)$ was calculated using the formula $V_{\mathrm{i}}=(K / \beta) \times(\bar{A})^{3 / 2}$, with $K=1.1$ and $\beta=1.5$, where $\bar{A}$ is the mean area of insulin-positive cells, $K$ is a size distribution coefficient calculated on the basis of islet size distribution, ${ }^{16}$ and $\beta$ is a shape coefficient calculated on the basis of minimum and maxim islet axis ratio. ${ }^{17}$ The density of islets per unit volume

Table 1 Blood Chemistry and Urinary Protein Excretion at 8 Months after Diabetes Induction

\begin{tabular}{lllcll}
\hline Group & BUN $(\mathrm{mmol} / \mathrm{L})$ & Creatinine $(\mathrm{mmol} / \mathrm{L})$ & ALT $(\mathrm{IU} / \mathrm{L})$ & AST $(\mathrm{IU} / \mathrm{L})$ & Proteinuria $(\mathrm{mg} / 24$ hours $)$ \\
\hline Control & $41.1 \pm 3.6^{\dagger}$ & $0.51 \pm 0.04$ & $87.3 \pm 12.9^{*}$ & $112.8 \pm 13.9^{*}$ & $135.0 \pm 29.2$ \\
Hyperglycemia & $75.6 \pm 10.2$ & $0.58 \pm 0.05$ & $137.1 \pm 14.3$ & $165.9 \pm 17.7$ & $106.5 \pm 17.8^{\dagger}$ \\
Moderate hyperglycemia & $51.9 \pm 4.5$ & $0.60 \pm 0.12$ & $88.1 \pm 17.0$ & $90.8 \pm 12.3$ & $546.9 \pm 161.5$ \\
Mild hyperglycemia & $47.5 \pm 5.0$ & $0.49 \pm 0.06$ & $76.0 \pm 19.2$ & $80.9 \pm 9.4$ & $318.5 \pm 86.0$ \\
Islet transplantation & $40.0 \pm 4.8$ & $0.55 \pm 0.05$ & $62.6 \pm 15.8$ & $81.4 \pm 20.0$ & $196.5 \pm 36.3$ \\
\hline
\end{tabular}

Data are expressed as means \pm SEM.

${ }^{*} P<0.05$, control versus hyperglycemia.

${ }^{\dagger} P<0.05$, hyperglycemia versus moderate hyperglycemia, islet transplantation, and mild hyperglycemia.

ALT, alanine transaminase; AST, aspartate transaminase; BUN, blood urea nitrogen. 

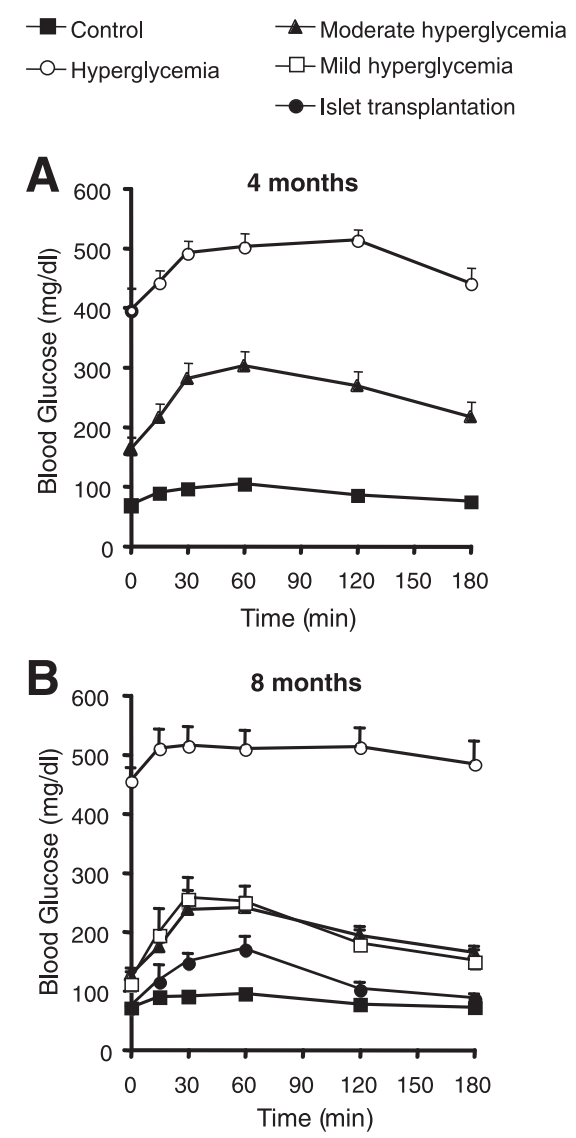

Figure 2 OGTT blood glucose values in male Sprague-Dawley rats at 4 months (A) and 8 months (B). Data are expressed as means $\pm \mathrm{SEM}$.

$\left(N_{\mathrm{V}}, \mu \mathrm{m}\right)$ was calculated using the formula $N_{\mathrm{V}}=N_{\mathrm{A}} /(\bar{D}-t)$, where $N_{\mathrm{A}}$ is the islet numerical density per unit of pancreatic area, $\bar{D}$ is the mean islet diameter (obtained from the mean islet volume), and $t$ is the section thickness (assumed to be $3 \mu \mathrm{m}$ ).

\section{Statistical Analysis}

Data were analyzed by analysis of variance, with comparisons between groups made by Bonferroni testing using StatView software version 5.1 (SAS Institute, Cary, NC). Data are expressed as means \pm SEM. Statistical significance was assumed at $P<0.05$.

\section{Results}

\section{Glycemia, Body Weight, and Urinary Excretion of Proteins}

All animals were carefully monitored during the entire 8-month period of the study. Nonfasting blood glucose concentration and body weight were measured weekly (Figure 1). Control rats maintained normal values of blood glucose and progressive body weight gain throughout the study. As expected, untreated diabetic rats consistently maintained serum glucose levels between 500 and $600 \mathrm{mg} / \mathrm{dL}$ over the 8 months, and growth was severely impaired during this period. Glucose control by insulin injection to maintain moderate hyperglycemia was effectively obtained (Figure 1A). Improvements in blood glucose control overcame the growth impairment observed in diabetic rats throughout the study (Figure 1B) $(P<0.01)$. Normoglycemia was restored 1 or 2 days after islet transplantation and was maintained for the entire observation period (Figure 1A). Transplanted rats displayed progressive body weight increase, reaching values similar to control rats. In rats with intensive insulin treatment, we did not succeed in complete restoration of normoglycemia (Figure 1A). Despite mild hyperglycemia, an improvement in body weight was also recorded in this group (Figure 1B). Data for urinary protein excretion at the end of the study are presented in Table 1. Of interest, in hyperglycemic animals urinary protein excretion was similar to that of normal controls at study end. In contrast, proteinuria increased in rats with moderate hyperglycemia, averaging $547 \pm 161 \mathrm{mg} / 24$ hours at 8 months. Insulin administration was not associated with any lowering of proteinuria that was significantly higher than in control group. Islet transplantation exerted an important antiproteinuric effect; proteinuria in these animals was similar to that of normal controls.

\section{Blood Chemistry}

Untreated diabetic rats had a significant increase in blood urea nitrogen, alanine transaminase, and aspartate transaminase values versus control animals $(P<0.05)$ at treatment start (data not shown). Both insulin administration and islet transplantation allowed normalization of these kidney and liver function parameters (Table 1).

\section{Plasma TBARS}

STZ-induced diabetes significantly tripled TBARS levels, from $0.220 \pm 0.022 \mathrm{nmol} / \mathrm{mL}$ in controls to $0.731 \pm 0.062$ in hyperglycemic rats $(P<0.01)$. In the moderate

Table 2 Blood Glucose AUC at 4 and 8 Months after Diabetes Induction

\begin{tabular}{lll}
\hline \multirow{2}{*}{ Group } & \multicolumn{2}{l}{ AUC (mg/dL per minute) } \\
\cline { 2 - 3 } & 4 months & 8 months \\
\hline Control & $16,142 \pm 347^{\star}$ & $15,085 \pm 268^{\star \dagger}$ \\
Hyperglycemia & $86,735 \pm 3379^{\ddagger}$ & $90,746 \pm 5609^{\ddagger}$ \\
Moderate hyperglycemia & $46,974 \pm 4406$ & $36,329 \pm 2524^{\S}$ \\
Mild hyperglycemia & & $35,851 \pm 4692$ \\
Islet transplantation & & $21,944 \pm 2180^{\natural}$ \\
\hline
\end{tabular}

Data are expressed as means \pm SEM.

${ }^{\star} P<0.001$, control versus hyperglycemia and moderate hyperglycemia.

${ }^{\dagger} P<0.05$, control versus mild hyperglycemia and islet transplantation.

${ }^{\ddagger} P<0.001$, hyperglycemia versus all other groups.

${ }^{\S} P<0.001$, moderate hyperglycemia versus islet transplantation.

$\Phi_{P}<0.05$, islet transplantation versus mild hyperglycemia. 
hyperglycemia group, TBARS levels remained significantly higher, compared with the control group. Islet transplantation and mild hyperglycemia significantly blunted plasma TBARS levels, to $0.401 \pm 0.025(P<0.05)$ and $0.367 \pm 0.062(P<0.01)$, respectively.

\section{OGTT}

An OGTT was performed at 4 and 8 months after the STZ injection in all groups. Blood glucose concentration and AUC were significantly higher after the glucose load in hyperglycemic rats, compared with control animals, at 4 and

A

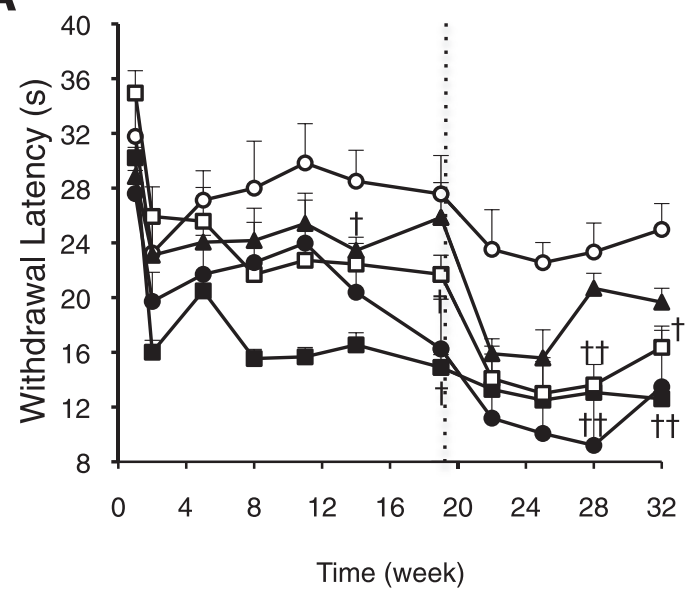

C

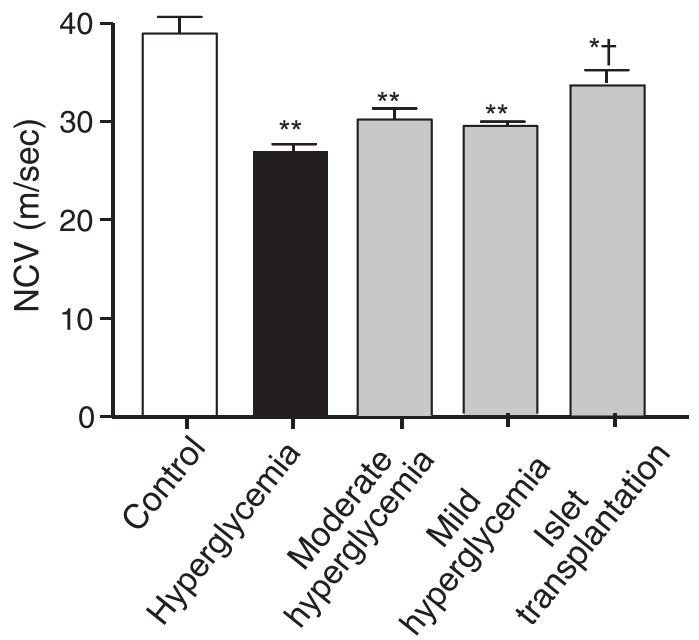

8 months (Figure 2 and Table 2). Insulin injections to maintain moderate hyperglycemia lowered the glucose swing both at 4 and 8 months (Figure 2). Stricter glycemic control in the mild hyperglycemic group did not further improve the OGTT curve (Figure 2B). Islet transplantation significantly improved both glucose swing and AUC at 8 months $(P<0.01)$ (Table 2).

\section{Thermal and Mechanical Nociceptive Thresholds}

The hind-paw thermal and force withdrawal thresholds were measured at baseline and monthly after induction of
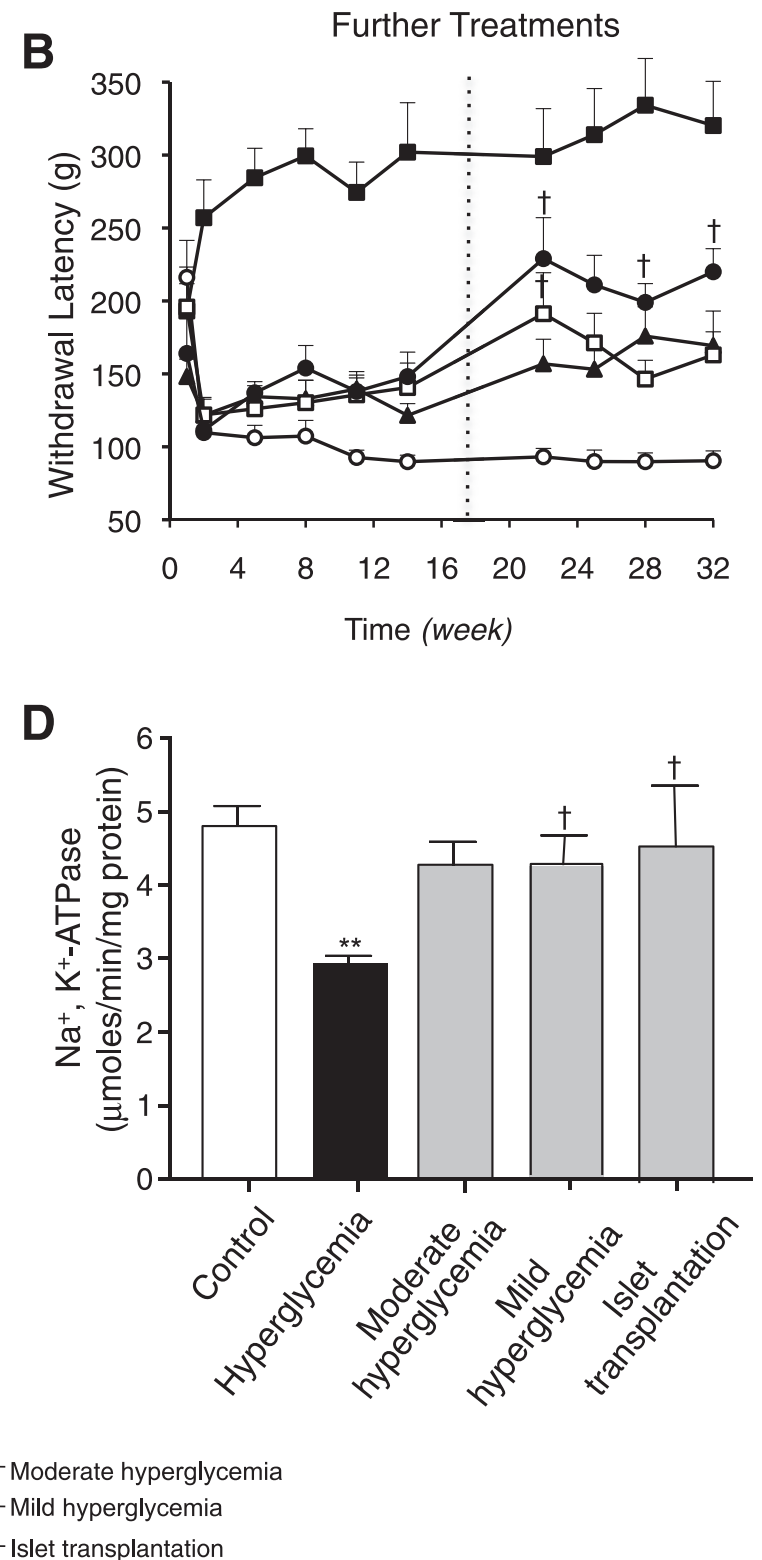

Figure 3 A and B: Thermal (A) and mechanical (B) nociceptive threshold over time. $\mathbf{C}$ and $\mathbf{D}$ : Nerve conduction velocity in the tail vein at 8 months $(\mathbf{C})$ and $\mathrm{Na}^{+}-\mathrm{K}^{+}$-ATPase activity at 8 months (D). Data are expressed as means \pm SEM. ${ }^{*} P<0.05$ for control versus moderate hyperglycemia, mild hyperglycemia, and islet transplantation. ${ }^{* *} P<0.001$ for control versus hyperglycemia, moderate hyperglycemia, and mild hyperglycemia. ${ }^{\dagger} P<0.05$ for hyperglycemia versus moderate hyperglycemia, mild hyperglycemia, and islet transplantation. ${ }^{\dagger \dagger} P<0.001$ for hyperglycemia versus mild hyperglycemia and islet transplantation. 
diabetes (Figure 3). Both thermal (hyposensitivity) and mechanical (hypersensitivity) nociceptive thresholds were significantly affected by hyperglycemia starting 2 weeks after STZ injection and persisting for the entire 8 months of testing. It is noteworthy that thermal hypoalgesia was highly dependent on control of glucose levels. In the moderate hyperglycemia group, only a long-term treatment triggered a beneficial effect (Figure 3A), whereas islet transplantation was more rapid and effective, restoring thermal sensitivity in approximately 1 month. Similar results were obtained in the mild hyperglycemia group.

Mechanical sensitivity was greatly affected by diabetes; the detection threshold decreased by $50 \%$ to $70 \%$ after 4 months in all diabetic groups (Figure 3B). Starting from a similar perception threshold, treatments progressively and significantly improved mechanical perception. Islet transplantation was the most effective treatment, reaching a 30\% reduction relative to controls at the end of the observation period.

\section{Nerve Conduction Velocity}

At 4 months after STZ injection, NCV was significantly reduced $(P<0.01)$ in the hyperglycemic group, compared with controls (data not shown). As expected, over the longterm study period NCV increased in the control group (from $32.7 \pm 1.0$ at baseline to $39.0 \pm 1.6 \mathrm{~m} / \mathrm{sec}$ at 8 months), whereas it was almost unchanged in diabetic animals (from $24.7 \pm 0.8$ to $26.9 \pm 1.3 \mathrm{~m} / \mathrm{sec})$. At the end of the study, islet transplantation led to a 50\% improvement in NCV $(P<$ $0.01)$; insulin treatments were less effective, with the animals still presenting a 25\% reduction in NCV (Figure 3C).

\section{$\mathrm{Na}^{+}-\mathrm{K}^{+}$-ATPase activity}

Diabetes reduced $\mathrm{Na}^{+}-\mathrm{K}^{+}$-ATPase activity in sciatic nerve, from $4.81 \pm 0.27 \mu \mathrm{mol} / \mathrm{min}$ per milligram protein in control rats to $2.93 \pm 0.10$ in the hyperglycemic group $(P<0.001)$ (Figure 3D). It is of interest that islet transplantation or insulin treatments in diabetic rats induced only a slight reduction in $\mathrm{Na}^{+}-\mathrm{K}^{+}$-ATPase activity (approximately $10 \%$ ), but the reduced levels were significantly different from the hyperglycemic group $(P<0.05)$.

\section{Pathological Assessment in Sciatic Nerve}

At light microscopy examination, no reduction in myelinated fiber density was evident. We very rarely observed actively degenerating fibers, in all diabetic animals. Similarly, we only rarely observed mild changes in myelin sheath structure in the largest myelinated fibers of diabetic rats, suggestive of myelinopathy (Figure 4). In view of the overall mild relevance of the pathological changes, the differences among groups were assessed morphometrically by means of $g$-ratio calculation. Using this quantitative approach, a significant increase in the $g$-ratio was observed in untreated diabetic rats versus controls $(0.686 \pm 0.003$ versus $0.647 \pm 0.003 ; P<0.01)$. All treatments significantly reduced the $g$-ratio, which averaged $0.629 \pm 0.002,0.655 \pm 0.003$, and $0.624 \pm 0.003$ in islet transplantation, mild hyperglycemia, and moderate hyperglycemia, respectively $(P<0.01$ versus untreated diabetic rats).

\section{Glucagon Analysis}

In control rat islets, $\alpha$ cells were localized at the periphery/ mantle zone and $\beta$ cells in the core of the islets (Figure 5).

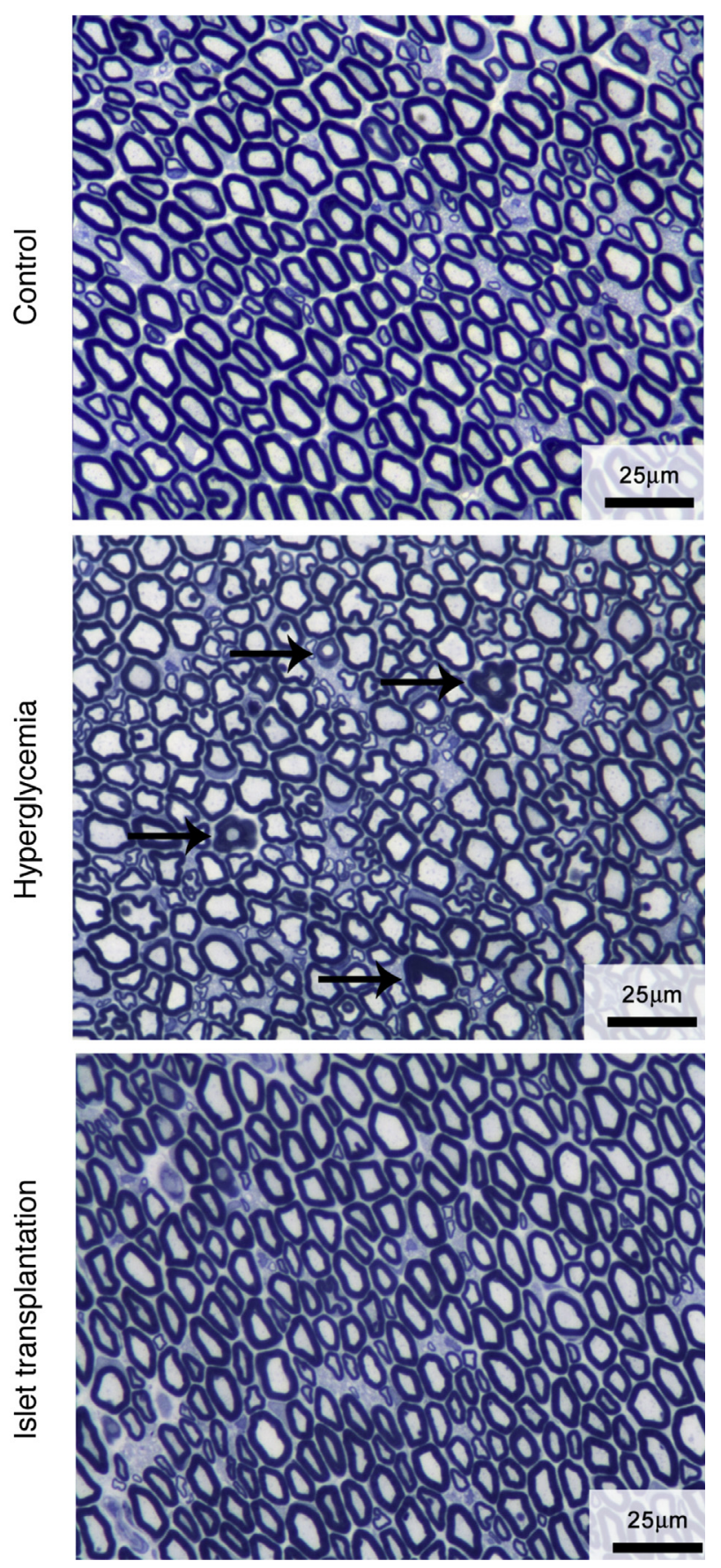

Figure 4 Representative images of sciatic nerve in control, hyperglycemic, and islet transplantation groups of rats. Degenerating fibers in hyperglycemic animals are indicated by arrows. Scale bar $=25 \mu \mathrm{m}$. Original magnification, $\times 40$. 

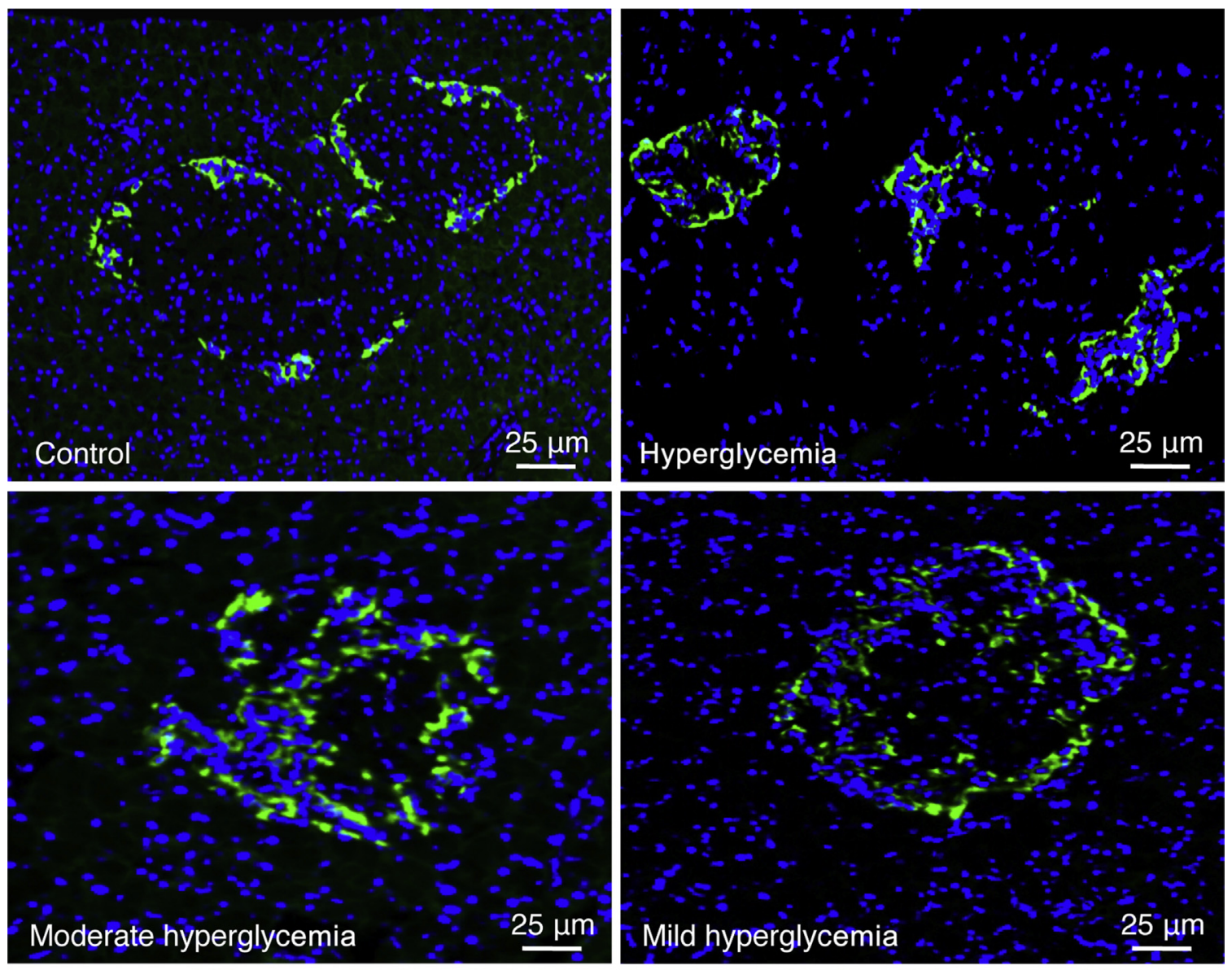

Moderate hyperglycemia

$25 \mu \mathrm{m}$
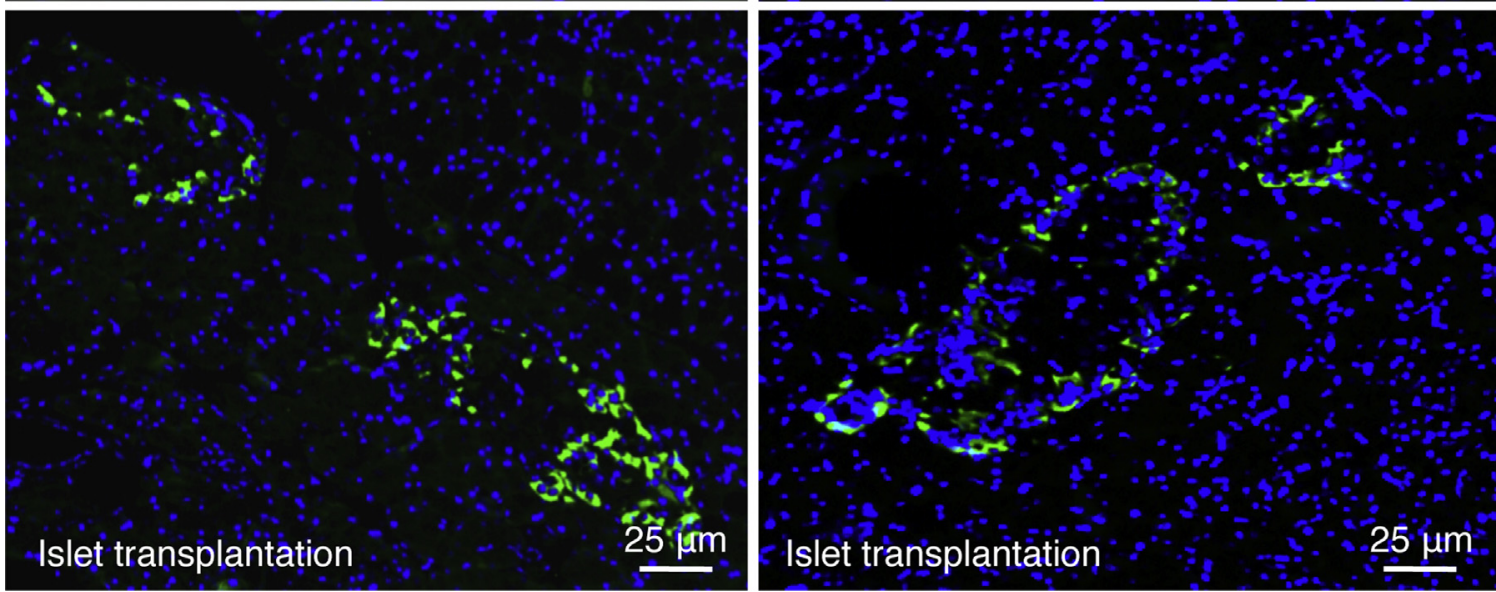

Figure 5 Representative images of stained glucagon cells in the five groups of rats at the end of the study. Two images for islet transplantation are shown Scale bar $=25 \mu \mathrm{m}$. Original magnification, $\times 20$.

After STZ injection, $\alpha$ cells started to expand into the core area and dominated the islets. No differences in the distribution of $\alpha$ cells were seen between the mild hyperglycemia and islet transplantation groups, compared with the hyperglycemia group (Figure 5).

\section{$\beta$-Cell Morphometric Analysis}

Volume density of $\beta$ cells in the pancreas of control rats averaged $0.83 \% \pm 0.17 \%$ and $1.25 \% \pm 0.13 \%$ at 4 and 8 months, respectively (Figure 6A). Insulin staining in hyperglycemic rats revealed minimal $\beta$-cell volume density $(0.02 \% \pm 0.00 \%$ positive cells at 4 months and $0.06 \% \pm$ $0.01 \%$ positive cells at 8 months). In contrast, $\beta$-cell volume density in rats with moderate hyperglycemia averaged $0.11 \% \pm 0.02 \%$ and $0.20 \% \pm 0.03 \%$ at 4 and 8 months, respectively. Similar $\beta$-cell volume was estimated in mild hyperglycemic rats, compared with moderate hyperglycemia. The maximum increase in $\beta$-cell volume occurred in rats with islet transplantation at 8 months, with 

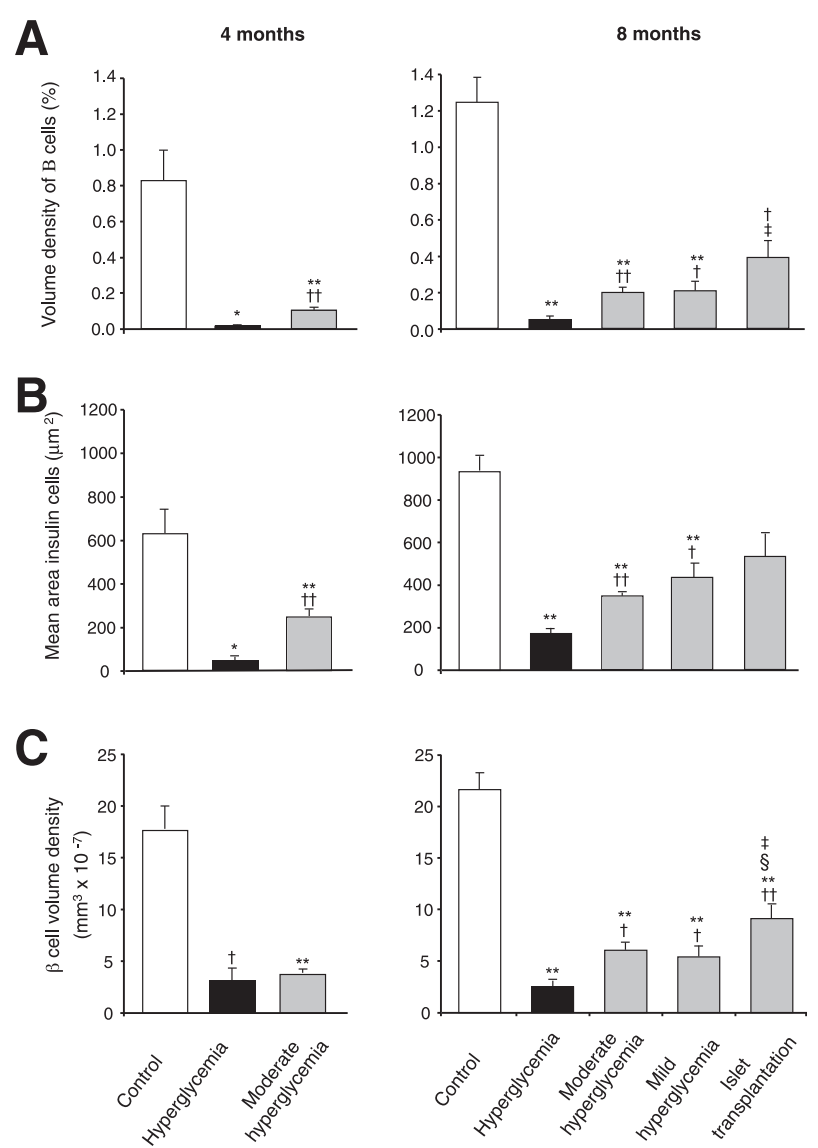

Figure $6 \quad \beta$-Cell analysis at 4 and 8 months in Sprague-Dawley rats for volume density of $\beta$ cells $(\mathbf{A})$, mean area of positive insulin cells $(\mathbf{B})$, and $\beta$ cell density per unit of volume $(\mathbf{C})$. Data are expressed as means \pm SEM. * $P$ $<0.05$ for control versus hyperglycemia and islet transplantation. ${ }^{* *} P<$ 0.001 for control versus all other groups. ${ }^{\ddagger} P<0.05$ for hyperglycemia versus moderate hyperglycemia, mild hyperglycemia, and islet transplantation. ${ }^{\ddagger \ddagger} P<0.001$ for hyperglycemia versus moderate hyperglycemia and islet transplantation. ${ }^{\ddagger} P<0.05$ for moderate hyperglycemia versus islet transplantation. ${ }^{\S} P<0.05$ for islet transplantation versus mild hyperglycemia.

$0.39 \% \pm 0.09 \%$ positively stained, compared with rats with moderate hyperglycemia $(P<0.05)$.

Similar results were obtained in the mean area of insulinpositive cells, indicating that $\beta$ cells in the islet transplantation group were organized in clusters resembling islets with almost half the size of control islets (Figure 6B). Representative images of insulin-stained cells of the five groups at 8 months are shown in Figure 7. Islets from the transplanted group were organized in a structure similar to native islets in pancreas of the control group.

$\beta$-cell density in islets of control rats was approximately $17.8 \pm 2.2 \beta$ cells $/ \mu \mathrm{m}^{3}$ at 4 months and $21.7 \pm 1.5 \beta$ cells $/ \mu \mathrm{m}^{3}$ at 8 months. In hyperglycemic rats, $\beta$-cell density was substantially reduced, by almost $83 \%$ at 4 months and by $87 \%$ at 8 months (Figure $6 \mathrm{C}$ ). In the moderate hyperglycemic group at 8 months, $\beta$-cell density averaged $6.1 \pm 0.72 \beta$ cells $/ \mu \mathrm{m}^{3}$. A statistically significant increase in $\beta$-cell density was observed in the islet transplantation treatment group at 8 months, compared with the moderate hyperglycemic group $(9.2 \pm 1.3$ $\beta$ cells $/ \mu^{3}$ versus $6.1 \pm 0.72 \beta$ cells $\left./ \mu \mathrm{m}^{3}\right)(P<0.05)$. Furthermore, $\beta$-cell density was slightly lower at 8 months, compared with the mild hyperglycemic group.

The volume density of $\beta$ cells showed a significant linear correlation with $\log$ values of glycemia both at 4 months $\left(R^{2}=0.78\right)$ and 8 months $\left(R^{2}=0.56\right)$, indicating that $\beta$-cell mass was strongly influenced by metabolic conditions (Figure 8).

\section{Discussion}

In type 1 diabetes, immune-mediated reaction induces destruction of pancreatic $\beta$ cells, leading to insulin deficiency and hyperglycemia. Replacement of $\beta$-cell mass with islet cells is considered a viable therapeutic option. Several experimental and clinical studies have shown that pancreatic islet transplantation prevents diabetes complications. ${ }^{18}$ Peripheral neuropathy is one of the most common long-term complications of diabetes and causes severe and prolonged morbidity, ${ }^{19}$ characterized by decreased NCV, as well as axonal degeneration, axoglial dysjunction, paranodal demyelinization, and loss of fiber density. ${ }^{20}$ In the STZ-induced diabetic neuropathy model, peripheral nervous system damage is represented by evident and reproducible functional neurophysiological and biochemical changes, ${ }^{21}$ paralleled by milder pathological changes. We have recently shown that transplantation of syngeneic encapsulated islets in diabetic rats induces regression of diabetic complications. ${ }^{4}$ Pancreatic syngeneic transplantation in the STZ-induced diabetes in the rat ameliorated impaired nociceptive thresholds and normalized NCV and $\mathrm{Na}^{+}-\mathrm{K}^{+}$-ATPase activity in the sciatic nerve. In the present study, in a disease model of longer duration (8 months), we evaluated the effect of metabolic control on the general condition of the rats and with a specific focus on peripheral nerve damage and islet restoration.

Although transplantation into the liver is the current practice for islet allotransplantation, it is now recognized that the liver may not provide the conditions favoring optimal islet survival. In particular, the vulnerability of transplanted islets in the immediate post-transplantation period and the exposure to higher glucose and immunosuppressive drug levels and hypoxic conditions in the portal circulation have been suggested to play a role in the initial $\beta$-cell loss. ${ }^{22,23}$ To offer a protective effect on transplanted islets, we performed transplantation with encapsulated islets, to exclude rejection and to avoid the toxic effects of immunosuppressive drugs on $\beta$ cells. The microencapsulated islets were implanted into the peritoneal cavity, which is a preferred site for transplantation, because the islets can be implanted with minimally invasive surgical procedures.

Our results show that microencapsulated allogeneic islet transplantation in diabetic rats achieved satisfactory glycemic control, as clearly indicated by a significant reduction in glucose excursion after the OGTT and a significant increase 


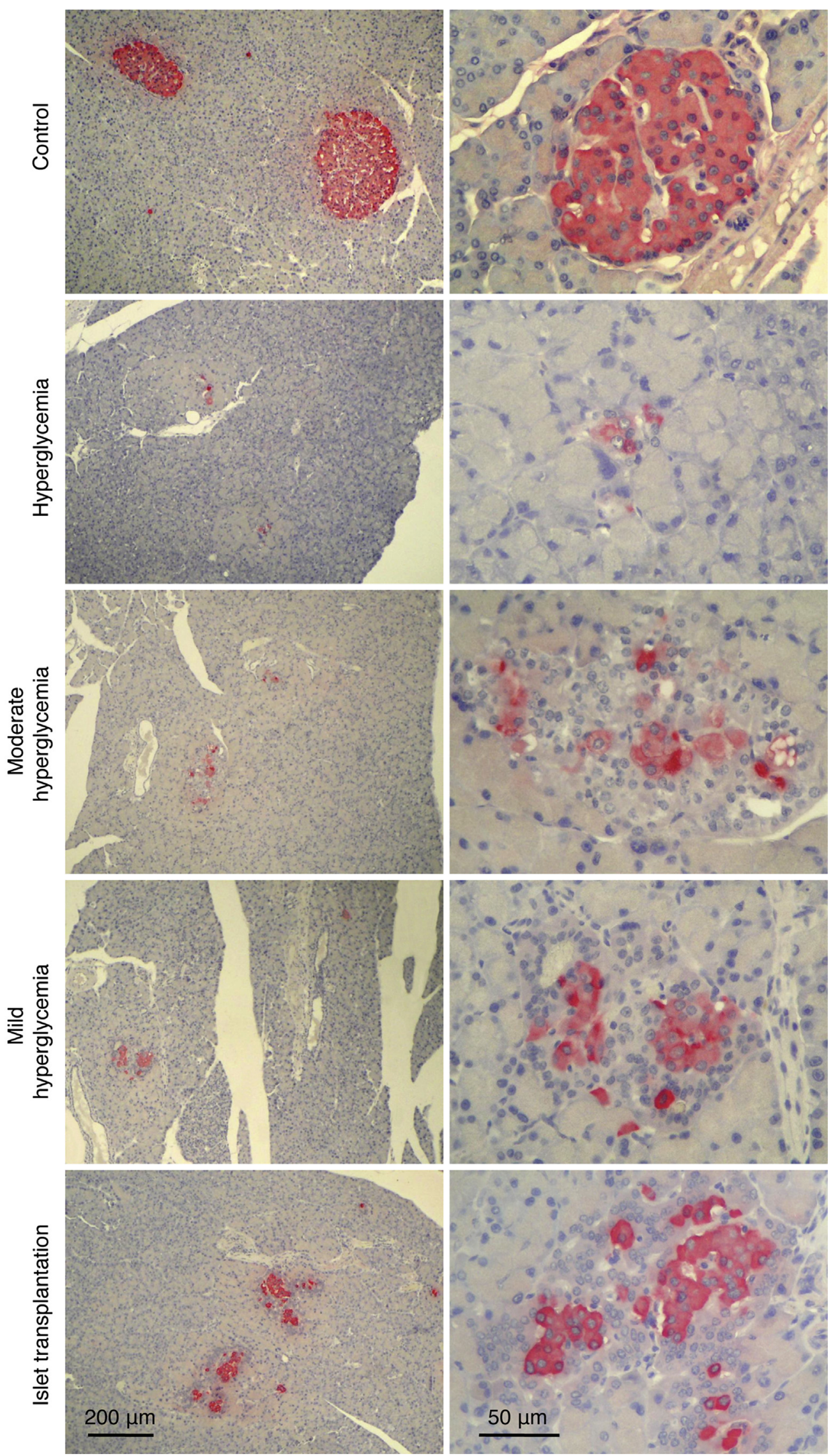

Figure 7 Representative images of stained insulin cells in the groups of rats at 8 months (end of study). Scale bars: $200 \mu \mathrm{m}$ (left); $50 \mu \mathrm{m}$ (right). 
in animal growth, together suggesting an improvement of the overall diabetic status.

We also observed a consistent reduction in liver impairment and in proteinuria, as well as a significant antioxidant effect in both the islet transplantation and the mild hyperglycemia groups. As might have been expected, better metabolic control and improvements in $\mathrm{NCV}$, nociception, and $\mathrm{Na}^{+}-\mathrm{K}^{+}-$ ATPase activity were associated with greater reduction in plasma TBARS levels (a biomarker of oxidative stress). In addition, islet transplantation was able to reverse loss of NCV induced by diabetes, whereas insulin treatment only partially prevented NCV reduction. Although others found that islet transplantation was not effective in preventing lesions in sciatic nerve of diabetic rats, ${ }^{24}$ our data are in agreement with those of Sima et $\mathrm{al}^{25}$ who found that islet transplantation completely prevented the typical slowing of NCV. We also demonstrated that insulin replacement, whether by islet transplantation or by intensive insulin treatment, counteracts the impairment of $\mathrm{Na}^{+}-\mathrm{K}^{+}$-ATPase activity. This might be a mechanism that improves neural function, because both enzymatic activity and NCV are mainly related to large myelinated fiber integrity. Our results demonstrate that islet transplantation effectively reduces peripheral neuropathy in animals with diabetes of long duration. Of note, also insulintreated rats with a better metabolic control had a similar improvement in neural function.

The STZ-induced diabetes model has been extensively used to investigate the function of transplanted islets. ${ }^{6,26}$ These studies were based on the assumption that animals treated with STZ are unable to recover endogenous $\beta$-cell function. Our data confirmed that, at 8 months after diabetes induction by STZ, only residual endogenous $\beta$-cell mass is present. The volume density and the mean area of $\beta$ cells were significantly reduced in the hyperglycemic group, compared with control $(0.056 \% \pm 0.015 \%$ and $174 \pm 26$ $\mu \mathrm{m}^{2}$ versus $1.249 \% \pm 0.135 \%$ and $938 \pm 68 \mu \mathrm{m}^{2}$, respectively). Histological examination of the pancreas of these rats showed that scattered insulin-positive cells mostly dispersed as single cells or in small clusters, unlike the wellorganized and clustered cells of the normal rat pancreas. Also, the pancreas of diabetic rats with moderate hyperglycemia, examined before transplantation, contained only few $\beta$ cells (an average of $0.11 \%$ insulin-positive cells). When the blood glucose concentration was normalized by islet transplantation, we observed an important increase of insulin-positive $\beta$ cells located inside the pre-existing islets. The mean area of clusters of positive cells was also increased in islet-transplanted rats, indicating that, in addition to increased number, the regenerated $\beta$ cells were distributed into an islet-like structure recreating the typical islet organization. We observed a lesser increased number of regenerated $\beta$ cells in rats with mild hyperglycemia, compared with the islet transplantation group, and these cells had a disorganized distribution. We also found a linear correlation between volume density of $\beta$ cells and glycemia at the single-animal level.
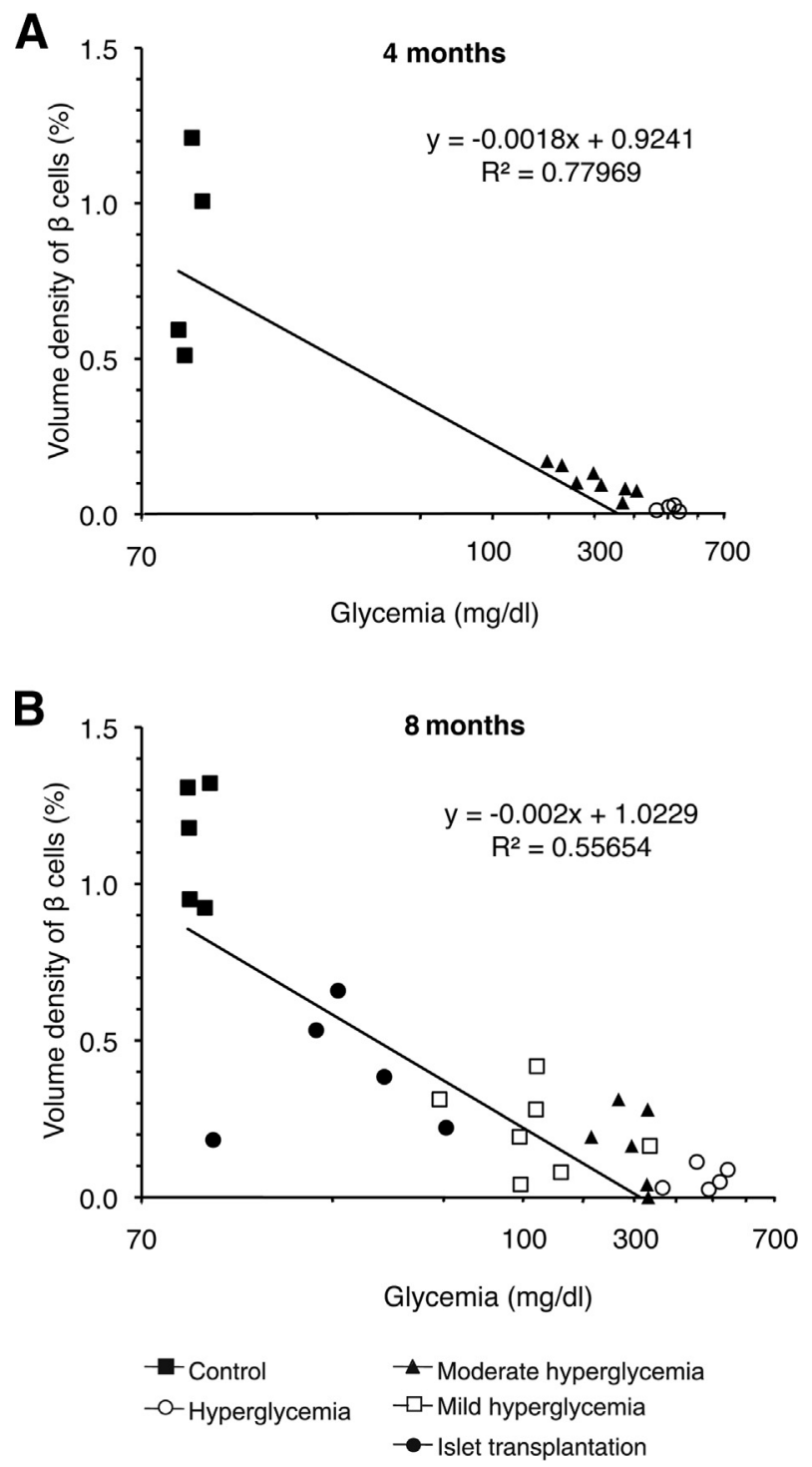

Figure 8 Correlation between volume density of $\beta$ cells and log value of blood glucose at 4 months (A) and 8 months (B).

As we expected, diabetes induction was characterized by distinct increases in $\alpha$ cells. In contrast to the $\beta$ cells, $\alpha$ cells were not affected by insulin or islet transplantation treatment. These results indicate that $\beta$-cell mass, but not $\alpha$-cell mass, is strongly influenced by metabolic conditions. Even though islet allotransplantation can provide prolonged insulin independence in rats with type 1 diabetes, the lack of $\alpha$-cell response to hypoglycemia after transplantation indicates that this procedure does not restore the physiological behavior of $\alpha$ cells. $^{27}$

The greater extent of $\beta$-cell regeneration obtained after islet transplantation, compared with intensive insulin treatment, indicates that re-establishment of normoglycemia is not the only factor involved in islet regeneration and that other factors must be taken into consideration. The present investigation was not focused on the mechanism of islet regeneration in transplanted diabetic rats; nonetheless, we must emphasize 
some important issues regarding $\beta$-cell regeneration after islet transplantation that need to be addressed and are worth investigating - in particular, the identification of the source of these important new $\beta$ cells. The question remains as to whether the new $\beta$ cells originate from undifferentiated precursor cells through neogenesis or from mitotic replication of differentiated $\beta$ cells. Understanding how $\beta$-cell regeneration is regulated could lead to identification of new approaches for enhancing $\beta$-cell regeneration.

In conclusion, our results indicate that normalization of blood glucose by islet transplantation improves neural function and induces partial regeneration of $\beta$ cells with islet-like organization in the pancreas. These findings strongly reinforce the need for improving glycemic control in patients, not only to reverse established diabetic complications but also to improve $\beta$-cell status in diabetic pancreas.

\section{Acknowledgments}

We thank Drs. Barbara Bonandrini and Irene Cattaneo for excellent technical assistance in pancreatic islet isolation and Dr. Sara Silvani for her technical assistance in performing the glucagon assay.

\section{References}

1. DCCT Research Group: Effects of age, duration and treatment of insulin-dependent diabetes mellitus on residual beta-cell function: observations during eligibility testing for the Diabetes Control and Complications Trial (DCCT). The DCCT Research Group. J Clin Endocrinol Metab 1987, 65:30-36

2. DCCT Research Group: The effect of intensive treatment of diabetes on the development and progression of long-term complications in insulin-dependent diabetes mellitus. The Diabetes Control and Complications Trial Research Group. N Engl J Med 1993, 329:977-986

3. Dyck PJ, Kratz KM, Karnes JL, Litchy WJ, Klein R, Pach JM, Wilson DM, O'Brien PC, Melton LJ 3rd, Service FJ: The prevalence by staged severity of various types of diabetic neuropathy, retinopathy, and nephropathy in a population-based cohort: the Rochester Diabetic Neuropathy Study [Erratum appeared in Neurology 1993, 43:2345]. Neurology 1993, 43:817-824

4. Remuzzi A, Cornolti R, Bianchi R, Figliuzzi M, Porretta-Serapiglia C, Oggioni N, Carozzi V, Crippa L, Avezza F, Fiordaliso F, Salio M, Lauria G, Lombardi R, Cavaletti G: Regression of diabetic complications by islet transplantation in the rat. Diabetologia 2009, 52:2653-2661

5. Biarnés M, Montolio M, Nacher V, Raurell M, Soler J, Montanya E: Beta-cell death and mass in syngeneically transplanted islets exposed to short- and long-term hyperglycemia. Diabetes 2002, 51:66-72

6. Figliuzzi M, Plati T, Cornolti R, Adobati F, Fagiani A, Rossi L, Remuzzi G, Remuzzi A: Biocompatibility and function of microencapsulated pancreatic islets. Acta Biomater 2006, 2:221-227

7. Bianchi R, Buyukakilli B, Brines M, Savino C, Cavaletti G, Oggioni N, Lauria G, Borgna M, Lombardi R, Cimen B, Comelekoglu U, Kanik A, Tataroglu C, Cerami A, Ghezzi P: Erythropoietin both protects from and reverses experimental diabetic neuropathy. Proc Natl Acad Sci USA 2004, 101:823-828

8. Randall LO, Selitto JJ: A method for measurement of analgesic activity on inflamed tissue. Arch Int Pharmacodyn Ther 1957, 111:409-419

9. Cavaletti G, Minoia C, Schieppati M, Tredici G: Protective effects of glutathione on cisplatin neurotoxicity in rats. Int J Radiat Oncol Biol Phys 1994, 29:771-776
10. Canta A, Chiorazzi A, Meregalli C, Carozzi V, Oggioni N, Lauria G, Lombardi R, Bianchi R, Porretta-Serapiglia C, Cavaletti G: Continuous buprenorphine delivery effect in streptozotocine-induced painful diabetic neuropathy in rats. J Pain 2009, 10:961-968

11. Pesaresi M, Giatti S, Cavaletti G, Abbiati F, Calabrese D, Bianchi R, Caruso D, Garcia-Segura LM, Melcangi RC: Sex differences in the manifestation of peripheral diabetic neuropathy in gonadectomized rats: a correlation with the levels of neuroactive steroids in the sciatic nerve. Exp Neurol 2011, 228:215-221

12. Bianchi R, Marini P, Merlini S, Fabris M, Triban C, Mussini E, Fiori MG: ATPase activity defects in alloxan-induced diabetic sciatic nerve recovered by ganglioside treatment. Diabetes 1988, 37: $1340-1345$

13. Scharschmidt BF, Keeffe EB, Blankenship NM, Ockner RK: Validation of a recording spectrophotometric method for measurement of membrane-associated Mg- and NaK-ATPase activity. J Lab Clin Med 1979, 93:790-799

14. Persohn E, Canta A, Schoepfer S, Traebert M, Mueller L, Gilardini A, Galbiati S, Nicolini G, Scuteri A, Lanzani F, Giussani G, Cavaletti G: Morphological and morphometric analysis of paclitaxel and docetaxelinduced peripheral neuropathy in rats. Eur J Cancer 2005, 41: 1460-1466

15. Cavaletti G, Tredici G, Marmiroli P, Petruccioli MG, Barajon I, Fabbrica D: Morphometric study of the sensory neuron and peripheral nerve changes induced by chronic cisplatin (DDP) administration in rats. Acta Neuropathol 1992, 84:364-371

16. Figliuzzi M, Zappella S, Morigi M, Rossi P, Marchetti P, Remuzzi A: Influence of donor age on bovine pancreatic islet isolation. Transplantation 2000, 70:1032-1037

17. Weibel ER: Stereological methods. Vol. 1: Practical methods for biological morphometry. London, Academic Press, 1979

18. Shapiro AM, Lakey JR, Ryan EA, Korbutt GS, Toth E, Warnock GL, Kneteman NM, Rajotte RV: Islet transplantation in seven patients with type 1 diabetes mellitus using a glucocorticoid-free immunosuppressive regimen. N Engl J Med 2000, 343:230-238

19. Brown MR, Dyck PJ, McClearn GE, Sima AA, Powell HC, Porte D Jr.: Central and peripheral nervous system complications. Diabetes 1982, 31:65-70

20. Vinik AI, Park TS, Stansberry KB, Pittenger GL: Diabetic neuropathies. Diabetologia 2000, 43:957-973

21. Boulton AJ, Vinik AI, Arezzo JC, Bril V, Feldman EL, Freeman R, Malik RA, Maser RE, Sosenko JM, Ziegler D; American Diabetes Association: Diabetic neuropathies: a statement by the American Diabetes Association. Diabetes Care 2005, 28:956-962

22. Thomas FT, Hutchings A, Contreras J, Wu J, Jiang XL, Eckhoff D, Thomas JM: Islet transplantation in the twenty-first century. Immunol Res 2002, 26:289-296

23. Van der Windt DJ, Echeverri GJ, Ijzermans JN, Cooper DK: The choice of anatomical site for islet transplantation. Cell Transplant 2008, 17:1005-1014

24. Spadella CT, Machado JL, Caramori CA, Gregório EA: Successful islet transplantation does not prevent the development of neuropathy in alloxan-induced diabetic rats. Transplant Proc 2002, 34: 1296-1300

25. Sima AA, Zhang WX, Tze WJ, Tai J, Nathaniel V: Diabetic neuropathy in STZ-induced diabetic rat and effect of allogeneic islet cell transplantation. Morphometric analysis. Diabetes 1988, 37: $1129-1136$

26. Li H, Colson YL, Ildstad ST: Mixed allogeneic chimerism achieved by lethal and nonlethal conditioning approaches induces donor-specific tolerance to simultaneous islet allografts. Transplantation 1995, 60: $523-529$

27. Paty BW, Ryan EA, Shapiro AM, Lakey JR, Robertson RP: Intrahepatic islet transplantation in type 1 diabetic patients does not restore hypoglycemic hormonal counterregulation or symptom recognition after insulin independence. Diabetes 2002, 51: $3428-3434$ 